\title{
The fraud rule under letter of credit law in the people's republic of China and implications for Vietnam
}

\author{
Bui Le Thuc Linh ${ }^{1,2, *}$
}

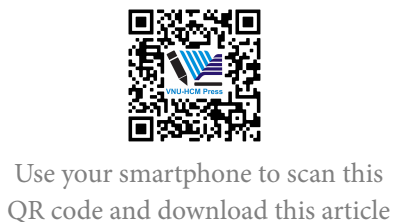

${ }^{1}$ University of Debrecen- Géza Marton Doctoral School of Legal Studies

${ }^{2}$ University of Economic and LawVietnam National University in Hochiminh city, Vietnam

\section{Correspondence}

Bui Le Thuc Linh, University of Debrecen- Géza Marton Doctoral School of Legal Studies

University of Economic and LawVietnam National University in Hochiminh city, Vietnam

Email: linhblt@uel.edu.vn

History

- Received: 15/11/2020

- Accepted: 4/3/2021

- Published: 31/3/2021

DOI : 10.32508/stdjelm.v5i1.722

\section{Check for updates}

\section{Copyright}

(.) VNU-HCM Press. This is an openaccess article distributed under the terms of the Creative Commons Attribution 4.0 International license.

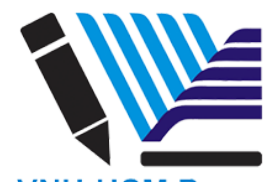

VNU-HCM Press

\begin{abstract}
In international trade where the buyer and the seller do not have information about each other, letter of credit is used to assure the other parties' fears in the sale contract. For instance, the sellers are afraid of not being paid after sending the goods bought by the purchasers, meanwhile, the buyers have no reasonable grounds to believe the sellers will send the conforming goods under the requirements of the sale contracts. The letter of credit is a settlement between parties to reduce the risks and inserts security into the international sale of goods. However, there are fraudsters who tries to defraud the process of the letter of credit and fraud rule is expected to prevent this issue. There are countries tried to develop specific regulations for the letter of credit and fraud rule, one of those countries is the People's Republic of China (P.R.C). The practices of letter of credit in China had been an aiming point of critiques through years by letter of credit experts. In such wise, the Supreme People's Court of P.R.C has issued the Rules of the Supreme People's Court Concerning Several Issues in Hearing Letter of Credit Case ("the 2005 Rules") in an effort to partly solve the problems.

This paper will give a brief introduction about the letter of credit's operation, the law regulating the letter of credit in international trade as well as illustrate the specify law for the fraud rule in letter of credit law in P.R.C by emphasizing the history and summarizing the structure of the fraud rule. Thenceforward, the author will evaluate the case study in Vietnam to show the situation of Vietnam in these days and giving recommendations.
\end{abstract}

Key words: Letter of credit, fraud, fraud rule, independence principle, UCP

\section{INTRODUCTION}

The documentary credit is now adopted universally in the global trade. The rationale of the letter of credit is to assure with the seller that they will get the payment in the sales contract for presenting the complying documents belonging to the requirements of the letter of credit. The main rationale for the reputation of the letter of credit is its special process. The payment will be continued regardless any problems happened in the underlying contract. This function is based on the most important rule, the independent principle. Nonetheless, the independent principle has one exception which is the fraud rule. Fraud rule allows the banks to cease their payments belonging the letter of credit if fraud is involved in the transactions even though the documents tendered by the presenter on the face complies with the obligations of the letter of credit. Fraud rule has created several debates over the years in the international trading world and create "the most controversial and confused area" ${ }^{1}$. People's Republic of China ( herein "P.R.C") can be seen as one of the largest customers in using letter of credit $\left[{ }^{2}, p\right.$. 1068]. In P.R.C, the widespread in using the letter of credit is not only affect the domestic business but also their foreign partners. The operations of procedures relating to the fraud in the letter of credit has been criticized for years and most of the critiques is originated from the actions of the applicants in China using the Chinese rules to quit the reimbursement obligation under the letter of $\mathrm{credit}^{2}$. It was not until late 2005 that the regulations for letter of credit are issued in P.R.C.

This article will invest in seeking and explaining the nature of letter of credit as well as classify its sources and regulations that govern the letter of credit. In the latter part, the author will explain the regulation of letter of credit and the fraud rule in P.R.C, and last part, the author will consider the situation in Vietnam by giving the opinion about Case Law.

\section{THE MECHANICS OF THE LETTER OF CREDIT}

\section{The mechanism}

The letter of credit is defined as a financial instrument which is autonomous with the sales agreement between the purchaser and the trader, yet it provides 
seller a promise to pay only if the seller can present complied documents, which show they had fulfill all the demands of the letter of credit $^{\mathrm{a}}$. In a classic letter of credit, the bank of the buyer will be required to release a letter of credit in favor of the trader. The purchaser will intruct the bank to draft a letter of credit with exact every single document that the buyer needs to obtain goods. The sole concern of the banks is whether the documents presented by the seller follow the requirements of the letter of credit. Once the seller hands out the documents, the issuer will inspect the documents whether they on the face conform the provisions of the letter of credit. If the documents meet the provisions, the issuer is obligated to pay the purchased price amount stated in the letter of credit $\left[{ }^{3}, \mathrm{p}\right.$. 178]. Likewise, the seller is guaranteed that they will be paid by an independent party [ ${ }^{4}$, p. 884$]$.

A simple letter of credit will involve at least three parties which is (1) the applicant (the buyer), (2) the issuing bank (the buyer's bank) and (3) the beneficiary (the seller). Three parties form three contracts which are:

1. A sale contract between the purchaser and the trader;

2. An application agreement where applicant demands issuer to issue a letter of credit; and

3. An agreement between the bank and the beneficiary- the letter of credit. ${ }^{5}$

\section{The Uniform Customs \& Practice for Docu- mentary Credits}

The most important international rules affecting practices of the letter of credit and generally accepted among bankers and dealers is the Uniform Customs \& Practice for Documentary Credits ("UCP"). The UCP is a precise declaration which is issued by the International Chamber of Commerce ("ICC"). In 1933, the first draft of UCP was completed ${ }^{6}$ and has been revised by the ICC after years. UCP 600 is the latest version ${ }^{7}$.

International parties have to draft a term within their financial contract to invoke UCP to govern their letter of credit. There are different opinions regarding to the

${ }^{a}$ Article 2 of The UCP 600 provides: Credit means any arrangement, however named or described, that is irrevocable and thereby constitutes a definite undertaking of the issuing bank to honor a complying presentation

${ }^{b}$ UCP means Uniform Customs and Practice for Documentary Credits - UCP 600. The ICC described Uniform Customs and Practice for Documentary Credits (UCP) are considered as the most outstanding private regulations that ICC has ever developed for trade. See more at http://store.iccwbo.org/icc-uniform-customs-and-pract ice-for-documentary-credits legal status of UCP. Most of the scholars agree with the main view which UCP is not a statute which has the law enforcement, UCP is only a set of international practices which is recognized by most of the countries in the world. For instance, in the Marine Midland Grace Trust Co. v. Banco del Pais, the court stated that "American law suggests that the UCP should not be construed in the same strict manner as a statute but as a contractual document prepared by businessmen." ${ }^{8}$. Or in the United Kingdom, as Lord Justice Megaw, Lord Justice Shaw and Lord Justice Waller stated "it has recently been observed that the Code does not have the force of law." ${ }^{9}$.

\section{The general rules of the letter of credit}

The foundation of the letter of credit law is the independent principle which make three contractual arrangements described above are independent from each other ${ }^{10}$. The independent principle is embraced in Article 4 of the UCP $600^{7}$. Article 4 acknowledges the letter of credit is self-reliant from the sales contract between purchaser and trader even though it is established base on the selling agreement. ${ }^{\mathrm{c}}$

Under the independent principle, the main concern of the bank is limited to payment obligation for the presenter, once the documents tendered conform the specifications of the letter of credit then the bank must pay [ ${ }^{11}$, pp. 392-393]. The issuing bank must honor the documents even though there are problems or conflicts happened within the sales contract between the purchaser and the trader [ ${ }^{12}, \mathrm{p}$. 957]. Issuing bank can only refuse to grant money once the documents submitted do not fit the requirements of the letter of credit. Otherwise, the issuer must pay even if there are breach of warranty, applicant goes bankrupt or even the underlying contract is cancelled $\left[{ }^{13}\right.$, pp. 186-188]. Alongside with the independent principle, principle of strict compliance also operates the letter of credit and is considered as an essential rule of letter of credit. Under this principle, the presenter has to prepare documents with every detail fit to the provisions described in letter of credit, for instance the

\footnotetext{
${ }^{c}$ UCP 600 , Article 4 ofUCP 600 provides: a. A credit by its nature is a separate transaction from the sale or other contract on which it may be based. Banks are in no way concerned with or bound by such contract, even if any reference whatsoever to it is included in the credit. Consequently, the undertaking of a bank to honor, to negotiate or to fulfil any other obligation under the credit is not subject to claims or defences by the applicant resulting from its relationships with the issuing bank or the beneficiary. A beneficiary can in no case avail itself of the contractual relationships existing between banks or between the applicant and the issuing bank. b. An issuing bank should discourage any attempt by the applicant to include, as an integral part of the credit, copies of the underlying contract, proforma invoice and the like.
} 
name of the parties must be exactly correct as stated in the letter. If the documents follow the principle of strict compliance, the banks' obligations are accepting and honoring the documents. As a consequence, documents tendered by beneficiary will be rejected if the documents do not follow the specific instructions, even though the beneficiary has fulfilled their obligations described in the sales contract in reality.

\section{The fraud exception}

Based on the independent principle, the obligations of the issuing bank are separated from the disputes arising from other transactions, however, this principle might have its exception in case of fraud [ ${ }^{14}$, p. 663]. The independent principle ensures to the beneficiary that he will be paid as long as he provides the complying documents. However, there is one loophole that the independent principle will be taken advantage, the fraudsters might take chances to harm the operation of the letter of credit by tendering the forged or fraudulent documents. This loophole in the letter of credit might be closed by the fraud rule.

Fraud exception is extraordinary as it is the only exception of the independent principle of the letter of credit. Fraud rule is usually used to avoid scammers to take advantages from other parties in the sale transaction as well as the letter of credit. It will be invoked once scams are involved in the agreements. A legal approach to fraud exception will create an stabilize apportionment for the parties' risks $\left[{ }^{15}\right.$, p. 385]. Under the fraud rule, even the documents presented to the bank seeming strictly complies with the conditions contained in the letter of credit, the payment for it might be paused if frauds are involved before the issuing bank pays the beneficiary [ ${ }^{14}$, p. 664]. Letting the fraudsters presenting the forged documents to the banks would lead to several harms to the benefits of various parties in the letter of credit. Once the faith between parties evaporate, the commerce utility of the letter of credit will collapse. To protect the financial advantages of the letter of credit as well as the faithful letter of credit users, the fraud rule must be used [ ${ }^{14}$, pp. 666-667].

Definition of fraud rule is also extremely important because setting standards for the fraud rule is quite complex. If we set the standards too high, the fraud rule would lose its effectiveness. The applicants would hesitate to adopt the letter of credit since they will not be protected from the fraudsters, which lead to the reduction in using the letter of credit and it will lose its commercial utility [ ${ }^{16}$, p. 334]. If the standards are too low, the applicant may take advantages from the fraud rule to prohibit the issuer from paying the presenter. The interference of the courts to the payment of the letter of credit is also a problem, if it keeps happening, the trust of business in letter of credit will be devastated ${ }^{17}$. The fraud rule must serve its functions for the merchants as well as is workable for the courts.

\section{THE FRAUD RULE UNDER THE LAW OF LETTER OF CREDIT IN THE PEOPLE'S REPUBLIC OF CHINA}

\section{The history of the law of letter of credit in P.R.C}

It has been years since the practices of the letters of credit in P.R.C. are criticized by international banks and letter of credit experts because the Chinese applicants and the banks are claimed that they tried to slip the payment obligation away by using the frauds ${ }^{18}$. In 1970s, the necessity to have the fraud rule in Chinese Legal Framework was clearly obvious, partly because the practices of the courts were found persistence $\left[{ }^{2}\right.$, p. 1068]. And it was not until late 2005 that P.R.C had their first proper rules in the letter of credit law $\left[{ }^{2}, p\right.$. 1068].

The problems with fraud rule in P.R.C's letter of credit cases began with Yuegang Agricultural Resources Development Co. v. Japanese Technology \& Science Co., ${ }^{19}$ in 1986. In the sales contract, the payment between parties was secured by a letter of credit worth $¥ 216$ millions. The plaintiff (Yuegang) claimed the feedstuffs of the machines delivered by the defendant Japanese Technology \& Science Co., did not meet the standards as mentioned in the sales contract ${ }^{2}$. The plaintiff then brought the action to the court and requested for an embargo to defer the reimbursement under the letter of credit. ${ }^{\mathrm{d}}$ An embargo was granted by the Court ${ }^{19}$.

The letter of credit specialists were extremely disappointed with the decision. Fraud was not cited in the case. The main allegation of the plaintiff was about the condition of goods, which was breach of warranty, so that the fraud rule should not be brought to the table. Wistfully, the Yuegang case is a presentation of the Courts' view in P.R.C in the early years $\left[{ }^{2}, p\right.$. 1071]. In the early years of economic transformation in P.R.C, the courts would naturally observe the instructions from the Civil Procedure Law of the P.R.C

\footnotetext{
${ }^{\mathrm{d}}$ The English translation of the case Yuegang Agricultural Resources Development Co. v. Japanese Technology \& Science Co., is taken from the translation of Xiang Gao (2007)
} 
(herein “CPL of P.R.C”). Under the Article $92^{\mathrm{e}}$ and Article $94^{\mathrm{f}}$ of CPL of P.R.C, they would suspend the process of paying of the bank without considering the independent rule of the letter of credit. The independent principle as well as the special mechanisms of the letter of credit were wholly neglected since the judges knew little about the economic utilities of this instrument. As a result, when the economy of China was blooming in 1970 s $\left[{ }^{2}\right.$, p. 1071$]$, the courts in P.R.C received several critiques from Chinese banks since they kept underestimating the independent principle and suspending payments of the letters of credit. The reason for this wave of denunciation was partially because the Chinese banks realized that their international positions were threaten and the economic benefits of the letter of credit was jeopardized since the court periodically meddled with the letter of credit payment $\left[{ }^{2}\right.$, p. 1072]

\section{The 1989 Summary}

Gradually, basing on the conscious of the structure of the letter of credit of the courts, the Supreme People's Court of P.R.C ( herein "SPC of P.R.C") constantly recognized that the situations where courts ceased the remittance of the letter of credit and took the letter of credit very much alike normal commercial instruments was not legitimate $\left[{ }^{2}\right.$, p. 1073].

Therefore, in December 1988, at the National Forum on the Adjudication of Economic Cases Relating to Foreigners and People from Hong Kong and Macao in the Coastal Region, the issue of pausing the remittance was discussed. Later, on June 12, 1989, the Summary of the National Forum on the Adjudication of Economic Cases Relating to Foreigners and People from Hong Kong and Macao in the Coastal Region was issued by the SPC of P.R.C (herein "1989 Summary")g and fraud rule was first mentioned in the summary.

\footnotetext{
${ }^{\mathrm{e}}$ Article 92 of CPL of P.R.C provides: If, as the result of an act of one of the parties to a case or for some other reason, it appears that a judgment may be impossible or difficult to execute, a people's court may, at the request of the other party, issue a property preservation ruling. In the absence of such a request, a people's court itself may also, if deemed necessary, order property preservation measures to be adopted. When taking measures for property preservation, a people's court may order the applicant to provide security. If an applicant fails to provide security, the application shall be rejected. On receiving an application, a people's court must, if the case is urgent, make a ruling within 48 hours. If it rules for the adoption of property preservation measures, execution of these measures shall commence immediately.

${ }^{\mathrm{f}}$ Article 94 of CPL of P.R.C provides: Property preservation shall take the form of sealing up, confiscation, the freezing of assets or other methods prescribed by law. If deciding that assets are to be frozen, a people's court shall immediately notify the party whose assets are to be frozen.

${ }^{\mathrm{g}}$ The English translation of the 1989 Summary is taken from Summary of the National Forum on the Adjudication of Economic Cases Relating to Foreigners and People from Hong Kong and Macao in the Coastal Region. "In view of the practice at home and abroad, if suf-
}

Based on these new provisions, the courts in P.R.C, especially those in high levels, when handling with the cases related to the letter of credit including frauds, can recognize the importance of the extraordinary characters of the letter of credit and grant their judgements with cautious when they are asked to enjoin a payment for the letter of credit. However, the 1989 Summary was underestimate because it does not have the enforcement of law and is only a policy statement of SPC of P.R.C ${ }^{2}$.

\section{The 2005 Rules}

The Supreme People's Court in P.R.C had tried to fill the lack of consistency in letter of credit rules and courts' practices. The Court then declared The Rules of the Supreme People's court Concerning Several Issues in Hearing Letter of credit Cases dated November 14, 2005 (herein "The 2005 Rule") ${ }^{20}$. One of the reasons was because the accusations of the Chinese banks since their positions in the international market were in danger. According to Xiang $\mathrm{Gao}^{2}$, the Chinese banks had performed a remarkable efforts to campaign the process of the 1998 Draft for years and had put a lot of efforts in commenting on the draft. The Banking Commission of ICC China held an important conference in January 2000 in Beijing for judges and commissioner of fourteen major banks in China to indicate their problems with the payment suspending of the letter of credit of the courts when frauds were involved in.

The 2005 Rules is basically a group of interpretations of legal rules. The Supreme People's Court of P.R.C has prepared specific instructions for several situations including specific cases to particular rules or peculiar guidance in special fields that law has not reached. The whole 2005 Rules covers the entire letter of credit field, but its main target is the fraud rule. It mainly focus on problem-solving rather than issuing a statute for letter of credit. Notwithstanding, the 2005 Rules was not considered as law but in realistic awareness, it is law since it has the enforcement of law and the courts keep citing it in their decisions $\left[{ }^{2}, \mathrm{p}\right.$. 1068].

ficient evidence shows that the seller is using the underlying contract defrauding the buyer, and the Chinese bank has not paid within a reasonable time, a people's court may freeze the payment of letter of credit upon the requirement of the buyer. However, a people's court should not freeze the payment of an acceptance credit when a time draft presented thereunder has already been accepted by the Chinese bank, as the obligation of the Chinese bank in such a situation has become unconditional under the law of negotiable instruments. [...] A people's court should follow the same steps mentioned when it receives an application from Chinese foreign arbitration agency for the freezing of the payment of a letter of credit." 
The 2005 Rules caps most of the problems of scams in the letter of credit including the fraud standard, those who are exempt from exercising the fraud rule, which courts could receive the applications from what parties and other issues. In general, the fraud rule under the 2005 Rules includes both procedural and substantive matters of the letter of credit law [ ${ }^{2}$, p. 1077].

\section{Standard of fraud}

Considering that letter of credit is a special economic device and the case studies for years of Chinese courts, Article 8 of the 2005 Rules $^{\text {h }}$ has create a new point of view in what situations that fraud rule could be invoke as follow:

"Any of the following shall be considered as letter of credit fraud:

- The beneficiary has forged documents or presented documents containing fraudulent information;

- The beneficiary has intentionally failed to deliver goods or deliver goods with no value;

- The beneficiary has conspired with the applicant or a third party and presented fraudulent documents whereas there is no actual underlying transaction; or

- Other circumstances that constitute letter of credit fraud." 20

As can be seen, the fraud standard under the 2005 Rules is defined considering to the special utility of the letter of credit. The 2005 Rules has narrowed the positions of fraud that can appeal to the fraud rule into the fraud in the documents or fraud in the underlying transaction. The documents would be considered as fraud if there are no documents at all and the beneficiary makes it up or the information included in the documents presented to the bank is fraudulent. The 2005 Rules wants to embrace another aspect of the fraud issues and suggests another allegation for the defraud parties in court. By the same token, the 2005 Rules also wants to emphasize that the standards of fraud rule are exceedingly high, only cases where there are no goods at all or goods with entirely no value could call upon the fraud rule under the 2005 Rules. In another way, it could be explained that if goods are delivered with low quality or lack of some units, it will not be deemed as fraud and parties cannot summon the fraud rule of the letter of credit.

Another special circumstance which is mentioned in the subsection (iii) mentions where there is no actual sale agreement. The 2005 Rules wants to indicate

\footnotetext{
${ }^{\mathrm{h}}$ The English translation of the Article 8 of the 2005 Rules is taken from the translation of Xiang Gao (2007).
}

that those who try to manipulate the banking system by using the invalid underlying contract and letter of credit for funds will be suspend by the courts if their intentions are revealed. Concerning there are people always trying to manipulate the system [ ${ }^{21}$, p. 9] and new fraud would not be listed in subsection (i), (ii) or (iii), the subsection (iv) is included. This subsection works under the name of security faucet to prevent any further dishonest acts in the future ${ }^{2}$.

\section{Exemption of fraud rule}

Having fraud rule embodied in the domestic law is not only to protect the defrauded parties but also to save innocent parties in the letter of credit transaction. However, fraud rule could not be invoked once the documents tendered by a holder in due course. One benefit of using the letters of credit is the beneficiary can receive money from a third party which is normally the beneficiary's local banks. These bank are known as intermediate banks [ ${ }^{2}$, p. 1080] which do negotiation or purchasing the documents that beneficiary presented or taking the right of proceeding the letter of credit under the name of warranty and providing loans to the beneficiary. When fraud is involved, the innocent parties such as issuing bank, applicant as well as the third parties will bear the loss. If third parties are not protected, the economy benefits of the letter of credit will be influenced since there will be fewer local banks willing to take the risks of negotiating the letter of credit, which leads to the reduction of sellers using this instrument. With these reasons, innocent third parties should be exempt from the exercising of fraud rule. Article 10 under the 2005 Rules $^{\mathrm{i}}$ declares about the immune parties along these lines: "A people's court shall make a ruling to suspend the payment or a judgement to permanently stop the payment under a letter of credit when fraud is established, unless one of the following has happened:

- The nominated person or the person authorized by the issuing bank has paid in good faith in accordance with the instructions of the issuing bank;

- The issuing bank or its nominated or authorized person has accepted the draft under the letter of credit in good faith;

- The confirming bank has paid in good faith; or

- The negotiation bank has negotiated in good faith." 20

${ }^{\mathrm{i}}$ The English translation of the Article 10 of the 2005 Rules is taken from the translation of Xiang Gao (2007). 
Under this provision of 2005 Rules, there are four circumstances which the fraud rule cannot be exercised to. The Court cannot apply the fraud rule when "nominated person" or authorized person have made their payment under "the instructions of the issuing bank" and requirements of letter of creditor when the documents tendered under the provisions of the letter of credit are accepted by the "issuing bank or its nominated or authorized person" with good faith ${ }^{20}$. As has been seen, through this subsection, the 2005 Rules has shown a truly narrowed way in approaching the fraud rule. In the situation where the payment is not paid right after the documents tendered but the deterrence payment, the payment will be delay for a certain time after the documents presented. In this case, the fraud rule could be invoked if the drafts tendered is accepted but no payment was made. To stop the payment, the applicant must apply for the injunction before the documents are presented. According to Xiang Gao $\left[{ }^{2}\right.$, p. 1082], this provision is "unfortunate" since all the parties holding the accepted documents will be exempt from the rule of fraud and this situation is "obviously defeats the whole purpose of the fraud rule" [ ${ }^{2}$, p. 1082].

The fraud rule also could not be invoked if the confirmer has paid to the presenter with good faith. Normally, the beneficiary wants to receive advices and payment from a local bank, so that issuer will authorize a beneficiary's local bank to honor the documents, this local bank is called confirming bank. To thirdparty presenter and the beneficiary, the confirming bank holds equal point as the issuing bank because it gives advices, accepts and honors the documents ${ }^{7 j}$. With good faith, the confirmer either accepts or refuses to honor the documents presented when fraud is found. Hence, as long as the confirmer pays with good faith, they are protected by the 2005 Rules [ ${ }^{2}$, p. 1082]. The fourth circumstance which the fraud rule could not be involved is when negotiation bank has handled the letter of credit with good faith ${ }^{20}$.

As stated, all four subsections under Article 10 of the 2005 Rules mention the "good faith" along with all process of parties under the letter of credit. In the light of Article 10 of the 2005 Rules, the good faith must be understood as "without notice of fraud" $\left[{ }^{2}\right.$,

${ }^{\mathrm{j}}$ Article 2 of UCP 600 provides: A confirming bank undertakes to reimburse another nominated bank that has honored or negotiated a complying presentation and forwarded the documents to the confirming bank. Reimbursement for the amount of a complying presentation under a credit available by acceptance or deferred payment is due at maturity, whether or not another nominated bank prepaid or purchased before maturity. A confirming bank's undertaking to reimburse another nominated bank is independent of the confirming bank's undertaking to the beneficiary. p. 1083]. In turn, under the guidance of Article 10 of 2005 Rules, when a negotiation bank honors the documents with good faith means that they do not have any ideas about the fraud within the transactions, and with that explanation, they can be exempt from the fraud rule. As a consequence, once the negotiation bank is noticed about the fraud included in the transactions but still negotiates the documents then the negotiation bank should not be protected.

However, this definition of good faith could not be applied when it comes to the position of confirming bank. Confirmer is in the same spot with the issuer from the perspective of beneficiary and third-party presenters, they must honor the documents tendered if the documents on the face comply the requirements under the letter of credit ${ }^{7}$. If the confirming bank turn the documents presented down because there are frauds within the transaction, he might find themselves being dragged into a litigation by the presenter. Accordingly, if the confirmer chooses to honor the documents presented on the face conforming the obligations of letter of credit even though fraud is involved and they notice it, the confirming bank must be secured by the rule of fraud because of its extraordinary condition. So in this circumstance, the "good faith" cannot be defined as "without notice of fraud" but "without collusion" with the fraudster $\left[{ }^{2}\right.$, p. 1083].

\section{Parties applying for Court remedies}

Under the Article 9 of 2005 Rules $^{\mathrm{k}}$, "[t]he applicant, the issuing bank or any other interested parties may apply to a competent people's court for a ruling to suspend the payment under the letter of credit [... ${ }^{\prime 20}$. Once fraud is found in the transactions, the applicant as the party standing in the priority position could bring the action to the court and ask for an injunction. The issuing bank is also listed as one of the parties applying for court remedies under the Article 9, however, according to Xiang $\mathrm{Gao}^{2}$, this is simply strange and illogical. Normally, the international practices and rules allow the issuer continues to honor the documents tendered as long as it conforms the obligations of letter of credit. Once fraud is found, the issuer can refuse to do so. And it is much more economical for the issuing bank to just turn the documents down than going to the court to ask for an injunction. Surprisingly, Chinese banks have different view about this provision comparing to Xiang Gao since they totally support this. According to Xiang Gao, the reason

\footnotetext{
${ }^{\mathrm{k}}$ The English translation of the Article 9 of the 2005 Rules is taken from the translation of Xiang Gao (2007).
} 
behind this encouragement is because they are afraid of their reputation will be affected if they refuse to honor a file because of fraud. It would be better for their fame if they reject the documents not by themselves but by courts' judgements [ ${ }^{2}$, p. 1085].

\section{THE IMPLICATIONS FOR THE LAW OF LETTER OF CREDIT IN VIETNAM}

\section{The law of letter of credit in Vietnam Legal Frameworks \\ The position of letter of credit law}

As a civil law country, issuing the letter of credit law and fraud rule will impose big effect on Vietnam Legal System because the courts trust and refer the statues and codes than cases law. However, the Vietnam Legal Frameworks barely mention about the law of letter of credit. There are few of regulations mentioned about the letter of credit such as Law on Negotiable instruments 2005 " $\mathrm{t}$ ] he parties to the negotiable instrument relationship may agree to apply international commercial practices, including the International Chamber of Commerce's Rules on uniform practice for documentary credits and the Uniform

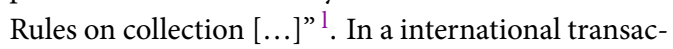
tion using the letter of credit as payment method, the bankers normally will search the universal practices in the UCP for international problems and answers for international framework of the letter of credit, including the definitions and the processes. The bankers and the merchants are expected to follow the international practices described in the UCP and also expect that they could receive the judgements based on the marketplaces and international standard practices. Another by-law document which had mentioned the letter of credit was Article $16^{\mathrm{m}}$ of Decision 226/2002/QD-NHNN dated March 26th, 2002 on The Issuance of The Regulation on Payment Activities Through Payment Service Suppliers (herein "De-

\footnotetext{
${ }^{1}$ Section 2, Article 6 of Law on Negotiable Instruments 2005.

${ }^{\mathrm{m}}$ Article 16 of Decision 226/2002/QD-NHNN provides: 1 . Letter of credit shall be a conditional written undertaking opened by banks at the request of a payment service user (the applicant for opening the letter of credit), under which, banks shall perform the requests of the payment service users (the applicant for opening letter of credit) in order to: - Effect the payment or authorize other banks to affect the payment immediately at the instruction of the payee upon receipt of a set of presented documents satisfying the conditions of letter of credit; or - Accept to make the payment or authorize other banks to make the payment at the instruction of the payee at a specific future time upon receipt of a set of presented documents satisfying conditions of letter of credit. 2. The opening, issuance, amendment, notification, confirmation, examination of the payment documents and rights, responsibilities, etc. of related parties in payment by letter of credit shall be applicable upon the agreement of parties engaging in the payment and in accordance with current applicable laws of Vietnam.
}

cision 226/2002/QD-NHNN"). Afterward, the Decision 226/2002/QD-NHNN was expired and the Circular 46/2014/TT-NHNN dated December 31, 2012 on Guidelines for Non-Cash Payment Services (herein "Circular 46/2014/TT-NHNN") took over from the Decision 226/2002/QD-NHNN. Article 16 in the Decision 226/2002/QD-NHNN was removed in the Circular 46/2014/TT-NHNN which means that there are no regulations related to the domestic letter of credit or fraud rule remaining in Vietnam Legal System.

\section{The Case Law No. 13/2017/AL}

The legal literature in Vietnam barely mentions the law of letter of credit but only admits the Uniform Customs and Practice as "de facto law" 22. The law of letter of credit in the Vietnam Legal Frameworks might not fascinate the expansion of using the letter of credit which might lead to the problem that happened in China in the late 1970s, which is situation when the applicant tried to use the court ' injunction to postpone the reimbursement under the letter of credit to get away their remittance responsibilities in the sale transaction. For instance, there is case which is listed in the Supreme People's Court of Vietnam's case law regarding the validity of letter of credit in the event that an international sale contract being the basis of the $\mathrm{L} / \mathrm{C}$ is cancelled - The Case Law No. 13/2017/AL. The Case Law No. 13/2017/AL is between A Ltd. v. $B$ (the names of the companies are changed to protect the commercial benefit of parties) in trading Ivory Coast raw cashew nuts. The contract contains the payment method using letter of credit of which performance is agreed to apply Uniform Customs and Practice for Documentary Credits 2007 (“UCP 600") of the International Chamber of Commerce and in compliance with the law of Vietnam. Condition and capacity of the products shall be inspected by Vinacontrol. An instructed Bank E (the issuing bank) to issue a letter of credit LC No. 1801ILUEIB110002 in favor of B, and Bank N (Singapore branch) was confirming bank. After receiving the cashew nuts, A brought the case to Court with the allegations that the quality of raw cashew nuts was low according to the inspection of the Vinacontrol and asked for applying a provisional measure to compel Bank E to temporarily suspend payment to the Seller. The Court had granted the temporary injunction No 101/2011/QĐBPKCTT. This embargo was opposed by Bank E and Bank $\mathrm{N}$ since they considered it as a violation to the UCP 600 rules. At first-instance court, the Court considered the LC No. 1081ILUEIB110002 was an integral part of the underlying contracts. Under Article 3.13 and Article 312 of the Commercial Law 
2012, the first-instance court declared that the sale contract was invalid. As a consequence, the LC No. 1081ILUEIB110002 was invalid too since the court considered it as an integral part of the contract of sale. Bank $\mathrm{E}$ is not obligated to reimburse to bank $\mathrm{N}$ under the LC 1801ILUEIB110002 since that letter of credit is canceled. Moreover, bank E must repay the deposit for the buyer. The temporary injunctive relief was applied until the judgement of the court was valid. Bank E submitted an appeal against the entire aforesaid first-instance commercial judgment. Through the procedure to open the hearing, the appellate court asserting that Bank E was absent without any force majeure reasons when it was summonsed for the second time and thus ruled to suspend the appellate hearing was a serious violation of the civil proceedings, which adversely affected the lawful rights and interests of the involved parties.

At the cassation of the Supreme People's Court of Vietnam, the Supreme People's Court had set aside Decision on suspension of the appellate hearing No. 29/2015/QDPT-KDTM dated 26 August 2015 of the Superior People's Court in Ho Chi Minh City and First-instance Commercial Judgment No. 356/2014/KDTM-ST dated 7 April 2014 of the People's Court of Ho Chi Minh City and transferred the case to the People's Court of Ho Chi Minh City to reconduct first-instance procedures. The Case Law No. 13/2017/AL had shown that the first-instance court failed to understand the letter of credit framework and it was an illustration for the lack of regulations for fraud rule in Vietnam.

The most important things in the cassation of the Supreme People's Court was the Supreme People's Court recognized the legal binding of the UCP 600 under the section 1 Article 19 of Decision No. 226/2002/QD-NHNN dated March 26, 2002 issued by The State Bank of Vietnam as well as recognized the independent rule of the letter of credit. At the recommendation in the Case Law No. 13/2017/AL, the Supreme People's Court of Vietnam notices the courts must realize the independence between the letter of credit and the sale transaction and even the underlying contract is invalid, the payment responsibility of the bank must be continued.

When handling the letter of credit, the courts must see the letter of credit as a special tool unlike the other negotiable instruments. Since the law of letter of credit is a complex area, the courts must be very careful in issuing their judgements. It is very dangerous for the positions of Vietnamese banks in international trading if the applicants try to quit their payment responsibilities by using the injunctions. At the same time, the
Vietnam Legal Framework will be under pressure by international letter of credit experts if the courts keep interfering with the payment obligations of the banks. The court in issuing their judgements must recognize the international practices of the letter of credit, not "what is reasonable, fair, or equitable?" 23.

\section{The proposal for the letter of credit law in Vietnam}

The UCP 600 is accepted in Vietnam ${ }^{22}$, hence, the courts and merchants in Vietnam can consult the UCP rules about definitions of the letter of credit and obligations of parties and etc. However, relying only on the UCP for the letter of credit is not a good idea because the UCP 600 is not complete. Once the letter of credit contains the governing clauses using the UCP 600, the litigation might be raised relating to several problems such as the rights and obligations of the parties once the documents presented involve frauds or remedies. The courts must look for an appropriate body of law ${ }^{24}$.

The legal framework of Vietnam should recognize the fraud exception of the letter of credit to keep up with the developing of the trade activities in Vietnam. The fraud exception will uphold the courts when dealing with specified cases related to the letters of credit and the frustrations of the courts will be solved when most of the provisions are combined at one set. There are few countries tried to embody the fraud rule into the domestic law such as the United States and the P.R.C. In the United States, in the early years, the legal scholars and experts in banking in the United States needed a case study to build the fraud rule structure. And Sztejn ${ }^{25}$ is a milestone to help developing the structure of the fraud regulations in the letter of credit law. It was drafted in the Uniform Commercial Code (U.C.C) and most of cases related to fraud rule have followed its rules in United States and throughtout common law world [ ${ }^{14}$, p. 676]. Referring to the law of letter of credit of US is remarkable because the United States is one of the biggest financial centers in the world, whereas the United States owns an enormous case laws which is very useful to consult. The drafters of the legal framework for the letter of credit law in Vietnam should appreciate the universal practices in the international rules such as UCP likes the drafters of Revised Article 5 of the Uniform of Commercial Code of the US had done since they adopted the UCP's approaches as well as their language $^{23}$. Additionally, the Rules of the Supreme People's Court Concerning Several Issues in Hearing Letter of credit Cases of P.R.C is also an important source 
because there are some similarities in legal framework between Vietnam and China.

The author proposes that a Judicial Interpretation issued by the Supreme People's Court of Vietnam on the legal interpretation of letter of credit and the fraud rule should be considered. This Judicial Interpretation should be adopted to handle with the litigations raised from the international letters of credit and their special features. The Judicial Interpretation should cover the essential elements of fraud rule in particular such as the independent principle, the standard of fraud, the exemption of the fraud exception and etc. Within the Judicial Interpretation, the most important element is the fraud standards. The standard should be drafted straightforward and defined the misconducts that can invoke the fraud rule like the 2005 Rules of the PRC. By giving the clear and narrow scope in the fraud rule, the Judicial Interpretation would provide a good guidance for the courts to apply the fraud rule without interfering the international practices of the letter of credit.

Other action should be defined in this Judicial Interpretation is what conducts will be taken once the fraud is involved to the transaction, which should be either 1) the bank should dishonor the documents or 2) the applicant or the bank should bring a court action to prevent payment. This part will be spelling out the procedural matters of the law when courts receive the allegations and issue the remedies as a consequence of fraud in the letter of credit. One more important problem should be considered is those who should be immune from the fraud rule. This matter should be clearly listed similar to the 2005 Rules or the drafters could refer to Article 5-109 of the UCC ${ }^{14}$. This procedural guidance will let the parties in the letter of credit out of the litigation confusion.

Nonetheless, forming a national legal law for letter of credit should remain the legal spirit in accordance with regulations of the Vietnamese Government. Legal experts and legislators also need to consult the international sources for the regulations of national letter of credit law in case of conflicting of law.

\section{CONCLUSION}

The legislation of the letter of credit in P.R.C and fraud rule was left behind without sufficient attentions when P.R.C open to the international trading in late 1970s. There were gaps between the practices of letter of credit and the regulations in the P.R.C legal framework, especially when P.R.C started their economic reform. However, a lot of efforts was put over years, P.R.C had issued the 2005 Rules including fraud regulations.
Vietnam is in the same situation with P.R.C since our economic is being developing and modernizing. Having the rule specified for the letter of credit and fraud rule will provide the courts stable legal source when working on the cases related to letter of credit. The law of letter of credit in general and the fraud rule in particular will cover most of the aspects of the letter of credit law and provide a substantial legal regulations referring to fraud rule such as the fraud measurement, the exemption of the fraud rule, parties who can ask for injunction and other specific court procedures. Hence, once dealing with cases relating the letter of credit, the courts can detect most of the provisions in one place.

With all of the advantages with having the law of letter of credit and fraud rule embodied within the national law, the legislators and letter of credit experts in Vietnam should work together to archive the best result for the law of letter of credit in Vietnam.

\section{ABBREVIATION}

ICC: The International Chamber of Commerce

UCP: Uniform of Customs and Practice

UCC: Uniform of Commercial Code

US: United States of America

PRC: People's Republic of China

CPL: Civil Procedure Law

SPC: Supreme People's Court

\section{CONFLICT OF INTEREST}

I hereby confirm that the manuscript has no actual or potential conflict of interest with any party, including but not limited to any financial, personal or other relationship with other people or organization within three years of beginning the submitted work that could inappropriately influence or be perceived to influence.

\section{AUTHOR CONTRIBUTION}

The works of the article is solely done by the author.

\section{REFERENCES}

1. Getz HA. Enjoining the International Standby Letter of Credit: The Iranian Letter of Credit Cases Havard International Law Journal. 1980;21(1):189-252.

2. Gao X. The fraud rule in Law of Letter of Credit in the P.R.C. The international Lawyer. 2007;41(4):1067-1090.

3. Barski KA. An Analysis of the Recent Revision to Article Five of the Uniform Commercial Code: Letter of Credit. Commercial Law Journal. 1996;101(2):117-ii.

4. Leacock SJ. Fraud in the International Transaction: Enjoining Payment of Letter of credit in International transactions.Vanderbilt Journal of Transnational Law. 1984;17(4):885-924.

5. United City Merchants Ltd. v. Royal Bank of Canada. 1982;.

6. International Chamber of Commercial, ICC brochure. 1933;82. 
7. International Chamber of Commerce, U.C.P 600. 2007;

8. Marine Midland Grace Trust Co. v. Banco del Pais. 1966;

9. Golodetz M \& Co., Inc. v. Czarnikow-Rionda Co., Inc. 1980:

10. Compass Bank v. Morris Cerullo World Evangelism, Corp. 2015;

11. Maurice O'Meara Co. v. National Park Bank of New York. 1925;

12. Howard DC. The Application of Compulsory Joinder Intervention, Impleader and Attachment to Letter of Credit Litigation. Fordham Law Review. 1984;52:957-966.

13. Ellinger EP. Documentary Letter of Credit- A comparative Study, Singapore: University of Singapore Press. 1970;.

14. Buckley RP, Gao X. Development of the fraud rule in letter of credit law: The journey so far and the Road ahead. University of Pennsylvania Journal of International Economic Laww. 2002;p. 663-712.

15. Houten SHV. Letter of Credit and Fraud: A Revisionist View. Canadian Bar review. 1984;62:371-388.

16. Gao X, Buckley RP. Acomparative analysis of the standard of Fraud required under the Fraud rule in Letter of Credit Law. Duke Journal of Comarative \& International Law. 2003;13(2):293-336.
17. Symons ELJ. Letter of credit: Fraud, Good faith and the Basics for Injunctive Relief. Tulane Review. 1979-1980;54(2):338-381.

18. International Chamber of Commerce. Special Report on China Trade- The Risk Factor. ICC Publication. 1996;548.

19. Yuegang Agricultural Resources Development Co. v. Japanese Technology \& Science Co. 1986;

20. Zuigao Renmin Fayuan Guanyu Shenli Xinyounzhen Jiaofeng Anjian Ruogan Wenti, The Rules of the Supreme People's Court Concerning Several Issues in Hearing Letter of Credit Cases, Adjudication Comm. of the Supreme People's Court. 2005;

21. Int'I Chamber of Commerce. ICC Commercial Crime Bureau Special Report- Prime Bank Instrument Frauds. 1994;

22. The National Assembly. Law on Negotiation Instrument 2005;.

23. Barnes JG. Internationalization of Revised UCC Article 5- Letter of Credit. Northwestern Journal of International Law \& Business. 1996;16:215-223.

24. Wood JS. Drafting Letters of Credit: Basic Issues under Article 5 of the Uniform Commercial Code, UCP 600, and ISP98. Banking Law Journal. 2008;125(2):103-149.

25. Sztejn v. Henry Schroder Banking Corp. 1941; 


\section{Quy chuẩn chống gian lận trong pháp luật thanh toán thư tín dụng chứng từ của nước Cộng hoà Nhân dân Trung Hoa và gợi ý cho pháp luật Việt Nam}

Bùi Lê Thục Linh ${ }^{1,2}$ **

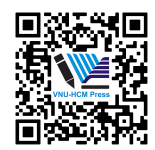

Use your smartphone to scan this QR code and download this article

${ }^{1}$ Géza Marton Doctoral School of Legal Studies- Trường Đại học Debrecen

${ }^{2}$ Giảng viên tại Trường Đại học Kinh tếLuạtt, Đại học Quốc gia TP.HCM, Việt Nam

Liên hệ

Bùi Lê Thục Linh, Géza Marton Doctoral School of Legal Studies- Trường Đại học Debrecen

Giảng viên tại Trường Đại học Kinh tế- Luật, Đại học Quốc gia TP.HCM, Việt Nam

Email: linhblt@uel.edu.vn

Lịch sử

- Ngày nhận: 15/11/2020

- Ngày chấp nhận: 4/3/2021

- Ngày đăng: 31/3/2021

DOI : $10.32508 /$ stdjelm.v5i1.722

\section{Check for updates}

\section{Bản quyền}

๑ ĐHQG Tp.HCM. Đây là bài báo công bố mở được phát hành theo các điều khoản của the Creative Commons Attribution 4.0 International license.

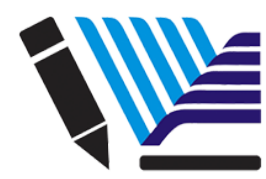

VNU-HCM Press

\section{TÓM TẮT}

Trong thương mại quốc tế, bên mua và bên bán thường không có thông tin về nhau, vì vậy thư tín dụng chứng từ thường được lựa chọn để sử dụng vì nó giải quyết được hầu hết các vấn để giữa người mua và người bán. Ví dụ, bên bán thường hay e ngại về việc không được thanh toán cho hàng hóa nếu họ gửi hàng trước, đồng thời, người mua cũng khồng tin tưởng người bán sẽ gửi hàng hóa theo như điều khoản hợp đồng đã thỏa thuận từ trước. Vi thế, thư tín dụng là một sự thỏa thuận giữa các bên để giảm thiểu bớt rủi ro và gia tăng bảo đảm trong việc mua bán hàng hóa quốc tế. Tuy nhiên, một số kẻ lừa đảo vẫn muốn thu lợi từ thư tín dụng chứng từ và quy chuẩn chống gian lận được thiết lập với mục đích ngăn ngừa vẩn để này. Một số quốc gia đã ban hành luật dành cho thư tín dụng chứng từ riêng, một trong số các quốc gia đó là Cộng hoà Nhân dân Trung Hoa. Các hoạt động liên quan đến thanh toán thư tín dụng chứng từ tại Trung Quốc đã từng bị các chuyên gia về thư tín dụng chứng từ chỉ trích rất nhiêu, vi thế, Toà án Tối cao của Trung Quốc đã ban hành Rules of the Supreme People's Court Concerning Several Issues in Hearing Letter of Credit Case (tạm dịch "Bộ quy tắc của Toà án Tối Cao về các vấn đề liên quan tới xét xử Thư tín dụng chứng từ") nhằm giải quyết phần nào các vấn đề liên quan đến thanh toán thư tín dụng chứng từ tại Trung Quốc.

Từ khoá: thư tín dụng chứng từ, gian lận, quy chuẩn chống gian lận, nguyên tắc độc lập, UCP
Trích dẫn bài báo này: Linh $B$ L T. Quy chuẩn chống gian lận trong pháp luật thanh toán thư tín dụng chứng từ của nước Cộng hoà Nhân dân Trung Hoa và gợi ý cho pháp luật Việt Nam. Sci. Tech. Dev. J. Eco. Law Manag.; 5(1):1348-1358. 